\title{
DAMPAK KINERJA KEUANGAN DAN TOTAL ASET TERHADAP KEPUTUSAN PEMBERIAN KREDIT BANK
}

\author{
${ }^{1 *}$ Dien Sefty Framita, ${ }^{2}$ Neneng Suprihatin, ${ }^{3}$ Dian Maulita \\ Universitas Serang Raya, Serang, Indonesia \\ *diensefty84@gmail.com
}

\begin{abstract}
Abstrak
Penelitian ini merupakan studi empiris yang bertujuan untuk menguji pengaruh kinerja keuangan dalam hal ini diukur dengan menggunakan rasio net interest margin dan total aset yang berasal dari pihak eksternal yaitu dana pihak ketiga dan pihak internal yaitu modal bank sendiri terhadap keputusan memberikan kredit bank di PT. Bank Mandiri Persero Tbk Periode 2012-2020. Desain dalam penelitian ini adalah kausalitas. Jumlah sampel dalam penelitian ini menggunakan time series untuk laporan keuangan triwulanan PT Bank Mandiri Persero Tbk selama 9 tahun dari tahun 2012 sampai dengan 2020 dan diperoleh 36 data. Teknik analisis yang digunakan dalam penelitian ini adalah regresi linier berganda, Hasil analisis menunjukkan bahwa secara parsial kinerja keuangan tidak berpengaruh terhadap keputusan pemberian kredit bank, sedangkan total aset berpengaruh terhadap keputusan pemberian kredit. Secara paralel, kinerja keuangan dan total aset berpengaruh terhadap keputusan pemberian pinjaman bank.
\end{abstract}

Kata Kunci: Kinerja Keuangan, NIM, Total Aset, DPK, CAR

\begin{abstract}
This research is an empirical study that aims to examine the effect of financial performance in this case measured by using the ratio of net interest margin and total assets originating from external parties, namely third party funds and internal parties, namely bank's own capital on the decision to provide bank credit at PT. Bank Mandiri Persero Tbk Period 2012-2020. The design in this study is causality. The number of samples in this study used a time series for the quarterly financial statements of PT Bank Mandiri Persero Tbk for 9 years from 2012 to 2020 and obtained 36 data. The analysis technique used in this study is multiple linear regression. The results of the analysis show that partially financial performance does not affect bank lending decisions, while total assets affect credit lending decisions. In parallel, financial performance and total assets affect bank lending decisions.
\end{abstract}

Keywords: Financial Performance, NIM, Total Assets, TPF, CAR

\section{PENDAHULUAN \\ Latar Belakang}

Aktivitas kredit merupakan tulang punggung aktivitas perbankan. Jika kita memperhatikan saldo bank, kita akan melihat bahwa aset aset bank didominasi oleh jumlah kredit, demikian pula jika kita melihat pendapatan bank, akan merugikan semua orang bahwa pendapatan bank terbesar berasal dari pendapatan bunga (Muchdasyar, 2005). Dominasi ini menyebabkan pendapatan bunga meningkatkan pendapatan bank secara keseluruhan. Di sisi lain, kredit memiliki tingkat risiko terjadinya kerugian, seperti kehilangan kredit dan pelunasan. Maka dari itu, bank selalu berpegang pada asas kehatihatian. Bank harus menghindari default bunga dengan tidak menaikkan biaya bank sehingga mereka dapat menekan atau bahkan membatalkan profitabilitas bank.
Dalam pengertian tersebut, sebagaimana telah dijelaskan sebelumnya, aktivitas perkreditan menimbulkan risiko yang biasa disebut dengan NPL (Non Performing Loop). Kredit bermasalah inilah yang dapat membuat bank enggan menyalurkan kredit kepada debitur (Dermawan, 2006). Kinerja keuangan yang diukur dengan NIM (net interest margin) adalah rasio antara laba bersih (pendapatan bunga bank yang dikurangkan dari beban bunga) dan kredit yang beredar (jumlah pinjaman yang diberikan). Dengan kata lain, semakin tinggi net interest margin maka semakin baik bank tersebut, karena ini berarti pendapatannya lebih besar dari ekuitasnya. Semakin bagus pendapatan perusahaan, jika jalur ini juga akan berdampak positif pada penyaluran kredit bank. (Dewi Masitoh, 2013).

Aset atau aktiva adalah harta kepunyaan entitas, yaitu, resource yang 
dikuasai oleh entitas publik atau investor privat yang terbuka untuk akun sebagai akibat dari aktivitas masa lalu dan manfaat atau manfaat di masa depan. (Jusup, 2011). Dalam hal ini, keuntungan dan keuntungan bank dapat diperoleh dengan menyalurkan aktivitas kredit. Sumber utama pembiayaan bank berasal dari DPK pihak ketiga (dana pihak ketiga) yang berperan penting dalam pemberian kredit. (Dendawijaya, 2009). Kegiatan bank yang pertama yaitu mengumpulkan dana dari warga umum dan setelah itu mendistribusikan kembali dana tersebut dalam bentuk pinjaman kredit kepada masyarakat yang membutuhkannya (Kasmir, 2014).

Sumber dana berikutnya adalah ekuitas bank, CAR (indeks kecukupan modal). Menurut (Mashud, 2004) CAR (indeks kecukupan modal) merupakan indeks permodalan yang menunjukkan kapabilitas modal perbankan yang disalurkan guna ekspansi bisnis guna menampung risiko kehilangan sumber daya yang disebabkan oleh Operasi bank. Semakin besar CAR maka semakin baik kondisi suatu bank. Menurut Ranitasari (2017).

\section{Rencana Pemecahan Masalah}

Penelitian ini dilakukan dengan melihat pengaruh kinerja keuangan, yang pengukurannya menggunakan indikator rasio antara net interest margin dengan total aset milik pihak ketiga yaitu dana pihak luar dan pihak dalam yakni ekuitas bank dalam keputusan pemberian kredit bank kepada PT. Banco Mandiri Persero, Tbk Periode 20122020.

\section{Rumusan Tujuan Penelitian}

Tujuan dari penelitian ini adalah peneliti mengukur dampak atau efek kinerja keuangan, yang pengukurannya menggunakan indikator rasio antara net interest margin dengan total aset milik pihak ketiga yaitu dana pihak luar dan pihak dalam yakni ekuitas bank dalam keputusan pemberian kredit bank kepada PT. Banco Mandiri Persero, Tbk Periode 2012-2020.

\section{Kajian Teoriitik}

Munawir (2018) meyatakan bahwa pengertian dari kinerja keuangan adalah "capaian suatu perusahaan yang diperoleh dalam periode tertentu dan terhutang dalam laporan keuangan yang bersangkutan. Sedangkan menurut Jumingan (2006), ia menjelaskan pemahaman tentang kinerja keuangan, yakni deskripsi situasi finansial entitas dan terkait dengan tingkat ekuitas dana, profitabilitas dan likuiditas, tingkat keuangan terkait. Menurut Fahmi (2012) mengemukakan bahwa "kinerja keuangan merupakan pengkajian untuk melihat sejauh mana aturan-aturan pengelolaan keuangan diaplikasikan oleh perusahaan dalam melaksanakan aktivitasnya secara akurat dan seksama . Sedangkan menurut Mulyadi (2012) menggambarkan pengertian kinerja keuangan yaitu kriteria-kriteria dalam mengelola keuangan secara tepat dan benar. Sedangkan menurut Mulyadi (2012) menjelaskan tentang efektivitas, kriteria efektivitas dan ditetapkan secara periodik bagi karyawan.

Aset atau Aktiva adalah kekayaan kepunyaan perusahaan, yaitu sumber ekonomi yang dikuasai oleh entitas publik atau penanam modal swasta yang terbuka sebagai akibat dari aktivitas masa lalu dan yang diharapkan dapat memberikan manfaat di kemudian hari. (Jusup, 2011). Aset adalah sumber ekonomi kepunyaan perusahaan yang dapat berbentuk satuan mata uang maupun barang dalam wujud yang real. Sources ini dinamakan aset atau aset ekonomi. Sumber dari aset entitas dapat berasal dari modal pengusaha sendiri, yang disebut ekuitas, dan kewajiban yang berbentuk pinjaman pihak ketiga atau luar entitas.

Asal kata kredit adalah credere diambil dari bahasa Yunani dengan makna "percaya". Tetapi yang umum di masyarakat menyamakan pengertian kredit dengan hutang. Banyak kita dapat temui masyarakat membeli barang dengan cara kredit, ini bukan sesuatu yang baru di tengah kegiatan masyarakat pada umumnya. Selain tidak secara tunai perdagangan kredit ini prosesnya relatif mudah. Secara umum, kredit adalah pemberian penggunaan suatu barang atau uang kepada orang lain di waktu yang tertentu dengan jaminan atau tidak dengan jaminan.

Menurut Dewi Masitoh (2013), nilai kredit yang diberikan bank dapat dilihat dari nilai kredit bank yang diberikan pada akhir 
periode laporan neraca. Menurut Joseph (2014) metode analisis pelaporan keuangan terdiri dari analisis vertikal dan analisis horizontal. Dalam penelitian ini, karena total kredit yang diberikan bank dapat mencapai jumlah yang sangat besar, maka akan disajikan melalui analisis vertikal. Item yang akan diukur dalam saldo adalah jumlah kredit yang diberikan, sehingga nilai pos dalam rumus tersebut digunakan untuk jumlah kredit yang diberikan atau kredit tertunda. Secara umum, cakupan analisis kredit, cakupan analisis harus membawa setidaknya analisis enam-C (6C), yang merupakan standar minimum yang umumnya digunakan saat berkredit.

\section{METODE}

\section{Rancangan Penelitian}

Metode penelitian yang digunakan dalam penelitian ini adalah kuantitatif. Penelitian ini merupakan penelitian kuantitatif yang bertujuan untuk menguji hubungan karena dua variabel atau lebih digunakan untuk menjelaskan pengaruh antara variabel independen dan dependen yang diteliti. Penelitian ini menggunakan pendekatan asosiatif kuantitatif. Pendekatan asosiatif adalah metode penelitian yang didasarkan pada filosofi positivisme. Desain penelitian ini adalah kausalitas.

\section{Populasi dan Sampel}

Populasi dalam penelitian ini adalah laporan keuangan PT Bank Mandiri Persero Tbk. Jumlah sampel dalam penelitian ini menggunakan time series untuk laporan keuangan triwulanan PT Bank Mandiri Persero Tbk selama 9 tahun dari tahun 2012 sampai dengan 2020 dan diperoleh 36 data.

\section{Teknik Pengumpulan Data Dan Pengembangan Instrumen \\ Teknik pengumpulan data} menggunakan teknik dokumentasi dan studi pustaka. Jenis data yang digunakan dalam penelitian ini adalah data time series sekunder berupa laporan keuangan triwulanan PT Bank Mandiri Persero Tbk selama tahun 2012 sampai dengan 2020.

\section{Teknik Analisis Data}

Teknik analisis yang digunakan dalam penelitian ini adalah regresi linier berganda, uji koefisien determinasi, uji $\mathrm{T}$, uji $\mathrm{F}$ yang diolah menggunakan aplikasi SPSS versi 25 .

regresi merupakan teknik statistik (alat analisis) hubungan yang digunakan untuk meramalkan atau memperkirakan dari satu variabel dalam hubunganya dengan variabel yang lain melalui persamaan garis regresi. Analisis regresi bisa berupa garis lurus (linear) dan nonlinear. Sementara analisis regresi pada penelitian ini adalah analisis regresi linear berganda, yaitu regresi yang melibatkan dua variabel yaitu variabel bebas (X1), variabel bebas (X2) dan satu variabel terikat (Y), Variabel independen terdiri dari kinerja keuangan (X1), total aset (X2) dan variabel dependen adalah pemberian kredit (Y).

\section{HASIL DAN PEMBAHASAN \\ Hasil Penelitian Uji T(Parsial)}

Pengujian ini digunakan untuk mengetahui apakah variabel independen secara parsial atau masing-masing memiliki pengaruh yang signifikan terhadap variabel dependen. Berikut adalah tabel hasil Uji T (Parsial).

\begin{tabular}{|} 
Tabel 1. Hasil Uji T (Parsial) \\
\begin{tabular}{|c|l|c|c|}
\hline \multicolumn{2}{|c|}{ Model } & T & Sig. \\
\hline \multirow{3}{*}{1} & (Constant) & $-6,837$ & 0,000 \\
\cline { 2 - 4 } & $\begin{array}{l}\text { Kinerja } \\
\text { Keuangan }\end{array}$ & 0,654 & 0,518 \\
\cline { 2 - 4 } & Total Aset & 9,277 & 0,000 \\
\hline
\end{tabular} \\
Sumber : Data diolah SPSS 25, 2021
\end{tabular}

Untuk melihat pengaruh parsial atau masing-masing X1 dan X2 pada Y dilihat dari Sig, $\mathrm{T}$ hitung dan $\mathrm{T}$ tabel dan hipotesis yang diajukan adalah:

\section{Pengaruh kinerja keuangan terhadap kredit}

Dari data output SPSS diatas dapat dianalisa sebagai berikut :

a. Nilai sig adalah 0,518 $>0,05$ maka $\mathrm{H}_{1}$ ditolak.

b. Nilai t hitung 0,654 dan t tabel dilihat dari (df $=n-1$; satu sisi) 1,689 yang berarti: 0,654<1,689 $\mathrm{H}_{1}$ ditolak.

Dari analisis data di atas dapat disimpulkan bahwa tidak terdapat pengaruh yang signifikan terhadap kinerja keuangan pemberi kredit. 


\section{Pengaruh total asset terhadap pemberian kredit}

Dari data output SPSS diatas dapat dianalisa sebagai berikut:

a. Nilai sig adalah 0,000 $<0,05$ maka $\mathrm{H}_{1}$ diterima

b. Nilai t hitung 9,277 dan t tabel dilihat dari (df $=n-1$; satu sisi) 1,689 yang berarti: 9,277>1,689 $\mathrm{H}_{1}$ diterima.

Dari hasil analisis data di atas dapat disimpulkan bahwa secara parsial terdapat pengaruh total aset terhadap pemberian kredit.

\section{Uji F(Simultan)}

Uji ini digunakan untuk mengetahui apakah variabel independen secara bersamasama berpengaruh signifikan terhadap variabel dependen. Berikut adalah tabel hasil Uji F (Simultan).

Tabel 2. Hasil Uji F (Simultan)

\begin{tabular}{|l|l|r|c|}
\hline Model & F & Sig. \\
\hline \multirow{3}{*}{1} & Regression & 43,524 &, $000^{\mathrm{b}}$ \\
\cline { 2 - 4 } & Residual & & \\
\cline { 2 - 4 } & Total & & \\
\hline \multicolumn{2}{|l}{ Sumber : Data diolah SPSS 25, 2021 }
\end{tabular}

Untuk melihat pengaruh secara simultan atau bersama-sama X1 dan X2 pada Y dilihat dari nilai Sig, hitung F dan tabel F dan hipotesis yang diajukan adalah:

\section{Pengaruh kinerja keuangan dan total aset terhadap penyaluran kredit.}

Dari data keluaran SPSS di atas dapat dianalisa sebagai berikut:

a. Nilai sig adalah $0,000<0,05$ maka $\mathrm{H}_{1}$ diterima

b. Nilai f hitung 43,524 dan $\mathrm{ftabel}$ dilihat dari (df1=k, df2=n-k-1) 3,28 yang berarti: 43,524 > 3,28 $\mathrm{H}_{1}$ diterima.

Dari hasil analisis data di atas dapat disimpulkan bahwa secara simultan terdapat pengaruh terhadap kinerja keuangan dan total aset dalam pemberian kredit.

\section{Pembahasan \\ Pengaruh Kinerja Keuangan terhadap Pemberian Kredit}

Bersumber dari hasil perhitungan SPSS 25 diperoleh nilai t hitung kurang dari nilai $t$ table $(0,654<1,689)$ dan nilai siginifikansi lebih besar dari 0,05 $(0,518>0,05)$ Sehingga $\mathrm{H}_{1}$ ditolak. Artinya tidak ada pengaruh secara parsial kinerja keuangan terhadap pemberian kredit. Hal ini tidak sejalan dengan hipotesis yang diajukan dan teori semakin tinggi rasio net interest margin dapat menunjukkan bahwa semakin efektif bank dalam menempatkan aktiva produktifnya dalam bentuk kredit (Susilo,2000) serta penelitian yang dilakukan Arianto(2017).Tidak adanya pengaruh kinerja keuangan yang diukur menggunakan net interest margin terhadap penyaluran kredit dikarenakan pada periode pengamatan net interest margin, tidak terjadi perubahan data yang signifikan sehingga signifikansi hubungan antar variabel menjadi kecil. Selain itu, tidak adanya pengaruh net interest margin terhadap penyaluran kredit dikarenakan net interest margin sebagai penghasilan bunga bersih bank yang ditahan (laba ditahan) yang dijadikan sumber pendanaan bank dalam komponen permodalan. Bunga bersih ini dimasukan kembali dalam modal kerja untuk operasional bank (Dendawijaya, 2009). Berdasarkan perspektif perbankan di Indonesia, tingkat net interest margin yang tinggi masih diperlukan untuk menutup resiko inflasi seperti potensi kerugian pada valas dan resiko kegiatan usaha di Indonesia (Ariyanto, 2017). Sehingga net interest margin juga difokuskan untuk menutupi resiko akibat inflasi dan tidak digunakan untuk penyaluran kredit.

Dari hasil penelitian ini dapat disimpulkan bahwa naik turunnya rasio net interest margin untuk mengukur kinerja keuangan tidak akan mempengaruhi pemberian kredit pada PT Bank Mandiri Persero,Tbk. Hasil penelitian ini sejalan dengan penelitian yang dilakukan oleh Sa'adah (2018), Ranitasari (2017), sertaPratiwi (2014).

\section{Pengaruh total asset terhadap pemberian kredit}

Berdasarkan hasil perhitungan SPSS 25 diperoleh nilai t hitung $>$ dari nilai t tabel $(9,277>1,689)$ dan nilai siginifikansi lebih kecil dari $0,05(0,000<0,05)$. Sehingga $\mathrm{H}_{1}$ diterima. Artinya terdapat pengaruh secara parsial total asset terhadap pemberian kredit. Terdapat pengaruh total aset terhadap penyaluran kredit, karena selama periode pengamatan total aset berubah secara signifikan sehingga hubungan yang signifikan antar variabel menjadi besar. Selain itu, terdapat pula pengaruh total aset terhadap penyaluran kredit karena total 
aset berasal dari pihak eksternal atau dana pihak ketiga dan pihak internal atau modal bank sendiri.

1. Dana pihak eksternal dilihat dari dana pihak ketiga, berpengaruh dan menunjukkan bahwa bank telah melaksanakan fungsinya dengan baik sebagai lembaga perantara keuangan. Hal tersebut tidak terlepas dari sifat usaha bank sebagai lembaga intermediasi antara pihak yang kelebihan dana dengan pihak yang kekurangan dana, dan sumber utama dana bank berasal dari masyarakat sehingga secara moral mereka harus menyalurkan kembali kepada masyarakat dalam bentuk kredit. Bank merupakan lembaga keuangan yang kegiatan usahanya adalah menghimpun dana dari masyarakat dan menyalurkannya kembali dana tersebut ke masyarakat serta memberikan jasajasa lainnya (Kasmir, 2014). Oleh karena itu, besaran penyaluran kredit sangat tergantung pada besaran dana yang tersedia terutama dana dari pihak ketiga.

2 Dana pihak internal berpengaruh karena modal bank berfungsi sebagai penanggung risiko kredit, dapat dilihat menggunakan rasio permodalan capital adequacy ratio (CAR) merupakan rasio permodalan yang menunjukkan kemampuan bank dalam menyediakan dana untuk keperluan pengembalian usahanya dan menampung risiko kerugian dana yang diakibatkan oleh kegiatan operasi bank atau kredit (Dendawijaya, 2009). Kredit atau pinjaman yang diberikan bank akan timbul risiko dikemudian hari misalnya nasabah tidak dapat mengembalikan kredit tersebut sesuai waktu yang dijanjikan dalam hal inilah modal bank berfungsi sebagai penanggung resiko kredit.

Dari hasil penelitian ini dapat disimpulkan bahwa naik turunnya total asset yang berasal dari pihak eksternal maupun internal mampu mempengaruhi pemberian kredit pada PT Bank Mandiri Persero Tbk. Hasil penelitian ini sejalan dengan penelitian yang oleh Sa'adah (2018), Ranitasari (2017), serta Pratiwi (2014)pengaruh kinerja keuangan dan total asset terhadap pemberian kredit.

\section{Pengaruh kinerja keuangan dan total aset terhadap pemberian kredit.}

Berdasarkan hasil perhitungan SPSS 25 diperoleh nilai $\mathrm{f}$ hitung $>$ dari nilai $\mathrm{f}$ table $(43,524>3,28)$ dan nilai siginifikansi lebih kecil dari 0,05 $(0,000<0,05)$ sehingga $\mathrm{H}_{1}$ diterima. Artinya terdapat pengaruh secara simultan kinerja keuangan dan total asset terhadap pemberian kredit. Dari hasil penelitian ini dapat ditarik kesimpulan bahwa kinerja keuangan dan total asset mempengaruhi pemberian kredit pada PT Bank Mandiri Persero,Tbk. Hal ini dikarenakan variable kinerja keuangan dan variabel total aset saling berkaitan satu sama lain dan memberikan kontribusi untuk mempengaruhi secara simultan terhadap variabel pemberian kredit.

\section{PENUTUP}

\section{Simpulan}

Secara parsial tidak terdapat pengaruh kinerja keuangan terhadap pemberian kredit. terdapat pengaruh total aset terhadap pemberian kredit. Secara simultan terdapat pengaruh kinerja keuangan dan total aset terhadap pemberian kredit.

\section{Saran}

Penelitian ini tidak terlepas dari sejumlah keterbatasan yang diketahui melalui pengamatan mendalam selama studi berlangsung. Ada beberapa kekurangan yang dirasakan peneliti dan mengambil langkahlangkah untuk memperbaiki kekurangan penelitian tersebut. Penelitian ini hanya menggunakan satu broker bank dalam hal ini PT. Bank Mandiri Persero, Tbk. Untuk penelitian lebih lanjut disarankan menggunakan banyak bank yang dapat digeneralisasikan berdasarkan hasil penelitian perbankan.

\section{DAFTAR PUSTAKA}

Ariyanto, T. (2017). FaktorPenentu Net Interest Margin Perbankan Indonesia. JurnalKeuangan dan Perbankan, 13(1)

Dewi Masitoh, Y. (2013). ANALISIS METODE CAMEL DALAM PENILAIAN KESEHATAN BANK SYARIAH dan 
BANK KONVENSIONAL DI INDONESIA YANG BELUM Go Public. FE (Manajemen), 8(9)

Indonesia, B. (1998). UndangUndangRepublik Indonesia No. 10 Tahun 1998 tentangPerbankan. Direktorat Hukum Bank Indonesia. Jakarta.

Jusup, A. H. (2011). Dasar-dasarAkuntansi, Edisi 7, Jilid 1. Sekolah Tinggi IlmuEkonomi YKPN. Yogyakarta.

Kasmir, S. E. M. M. (2014). Bank dan Lembaga KeuanganLainnya. Edisirevisi.

Mashud, A. (2004). Asset Liquidity Management, MensiasatiResiko Pasar dan ResikoOperasional, Jakarta. PT. Gramedia.

Munir, F. (2002). Hukum PerkreditanKontemporer. Bandung, CetakanKedua, EdisiRevisi, Citra Aditya Bakti.

Prabowo, A. (2013). Pengaruh Dana PihakKetiga (Dpk), Capital Adequacy Ratio (Car), Non Performing Loan (Npl) TerhadapPenyaluranKredit Usaha Rakyat (Kur). StudiKasus Pada Pt. Bank Mandiri (Persero) Tbk (Doctoral dissertation, Universitas Brawijaya).

Pratiwi, S., \&Hindasah, L. (2014). Pengaruh Dana PihakKetiga, Capital Adequacy Ratio, Return Non Asset, Net Interest Margin Dan Non Performing Loan TerhadapPenyaluranKredit Bank
Umum

Di

Indonesia. JurnalManajemenBisnis, $5(2$ ), 192-208.

Ranitasari, R. R. (2017). Pengaruh DPK, LDR, CAR, NPL, Dan NIM TerhadapPenyaluranKredit Pada Perusahaan PerbankanSwastaDevisa Nasional Yang Terdaftar Di Bank Indonesia Periode 2011-2015 (Doctoral dissertation, STIE PERBANAS SURABAYA).

Riyadi, S. (2003). Banking assets and liability management.

Sa'adah, N. (2018). Pengaruhdpk, car, nim, roa dan ldrterhadappenyalurankredit pada busndevisa dan busn non devisa yang terdaftar di bei (Doctoral dissertation, UNIVERSITI TEKNOLOGI MARA).

Simorangkir, O. P. (2004). Selukbeluk Bank Komersial, cetakankelima. Jakarta: Persada Indonesia.

Sugiyono, P. Dr. 2010. MetodePenelitianKuantitatif, Kualitatif, dan R\&D. Bandung: CV Alfabeta.

Susilo, Y. Sri; SigitTriandaru dan A. Totok Budi Santoso. 2000. Bank dan Lembaga Keuangan Lain.

Triandaru, S., \&Budisantoso, T. (2006). Bank dan Lembaga Keuangan Lain. Jakarta: Salemba Empat. 